УДК 811.161

UDC

DOI: $10.17223 / 18572685 / 50 / 11$

\title{
THE IMPROVEMENT OF THE ORTHOGRAPHIC RULES IN THE BACHKA-SREM RUSIN LANGUAGE*
}

\author{
M. Feysa \\ Novi Sad University \\ 1 Zoran D`ind`ich Street, Novi Sad, 21000, Serbia \\ E-mail: fejsam@gmail.com
}

\section{Abstract}

More than four and a half decades have passed since the publication of the first Orthography Rule-Book of the Rusin Language by Nikola N. Kochish in 1971. The Orthography Rule-Book established the basic orthographic principles of the Rusin language, yet some secondary problems were not treated at all or were treated inconsistently. In this paper, the author provides a solution to the remaining orthographic problems. In the first part of the paper, he classifies the problems. In the second part of the paper, he focuses on updating and improvement of the Kochish's Orthographical Dictionary of the Rusin Language, which resulted in the new Orthographic Dictionary of the Rusin Language published by the Department of Rusin Studies in 2017.

Keywords: Rusin (Rusyn) language, orthography, orthographic dictionary, doublets, loanwords, verbs.

\section{УСОВЕРШЕНСТВОВАНИЕ ОРФОГРАФИЧЕСКИХ ПРАВИЛ В ЯЗЫКЕ БАЧКО- СРЕМСКИХ РУСИНОВ}

\section{М. Фейса \\ Университет Нови Сад}

Сербия, 402920, г. Нови Сад, ул. Доктора Зорана Джинджича, 1

\footnotetext{
* The paper is part of Projects Nr. 187002 and Nr. 187017 supported by the Ministry of Education, Science and Technological Development of the Republic of Serbia.
} 


\section{Авторское резюме}

Прошло более четырех с половиной десятилетий с момента издания первой «Орфографии русинского языка», составленной Миколой М. Кочишем в 1971 г. В «Орфографии» были установлены основные правила правописания русинского языка, однако некоторые вторичные проблемы либо совсем не рассматривались, либо исследовались непоследовательно. В данной статье делается попытка решить оставшиеся орфографические проблемы. В первой части статьи автор рассматривает эти проблемы и разделяет их на несколько групп. Во второй части внимание фокусируется на модернизации и обновлении орфографического словаря русинского языка Кочиша, результатом которых явился новый «Орфографический словарь русинского языка», изданный в 2017 г. кафедрой русинистики.

Ключевые слова: русинский язык, орфография, орфографический словарь, дублеты, заимствованные слова, глаголы.

\section{Introduction}

Ever since the first Rusins settled in Bachka in the middle of the 18th Century (Gavrilovich 1977; Feysa 2010) and up to the First World War, they were predominantly farmers. Their craftsmen were organized in a guild, while there were very few priests and teachers. In time, the Rusins even made progress in their economic, national and cultural life. They succeeded in preserving their identity. They formed their language (Feysa 2000; Feysa 2004; Magocsi 2004) and raised it to the level that they could use it to print books. The first book in the Rusin language is the poetic wreath From My Village by Havriyil Kostel'nik published in 1904.

After the end of the First World War, within Serbia (or the Kingdom of Serbs, Croats and Slovenians, or, later, the Kingdom of Yugoslavia), the Rusins were permitted to form national and cultural institutions by virtue of the collective rights of all national minorities, which was not the case in their homeland. They were granted the status of national minority of Slavic origin in 1919, first and for many years to come the only one among their kinsmen in the Carpathian area. This was an event of utmost importance which opened the way of their national and cultural development (Horn'ak 2006: 25).

Under such circumstances the Rusins felt that the founding of the Rusin Popular Educational Society, the so-called Prosvita / Education, was the first step in which they manifested their striving for an independent national cultural life. At the founding meeting, on the $2^{\text {nd }}$ of July 1919 in Novi Sad, the Rusin national community decided to elevate 
its colloquial language (not the Russian or Ukrainian languages) to the level of a literary language. The first cultural-educational organization adopted resolution to use its everyday speech in the education, cultural life and the press. This decision was based on the fact that books of religious and literary character had already been published in this language (Med`eshi 1993: 146). The first Rusin cultural organization published several books of great significance. The most influential book of the time was the first Rusin grammar Grammar of Bachka-Rusin Speech by Havriyil Kostel'nik (1923). Both Rusin and Slavic linguists are indebted to Havriyil Kostel'nik - as the codifier of the Rusin language of the Rusins in Serbia / Vojvodina and as the creator of the Rusin linguistic terminology.

The second Grammar of the Rusin Language was published by Nikola N. Kochish (1977) and the third Grammar of the Rusin Language was published by Yuliyan Ramach (2002).

\section{The First Steps in Making Orthography Rules}

The first Orthography Rule-Book of the Rusin Language was written by Nikola N. Kochish in 1971. Generally speaking Orthography RuleBook of the Rusin Language achieved its main goal - to establish the basic orthography rules. The proposed orthography rules were applied in the second part of the book, that is in the Orthographic Dictionary of the Rusin Language (Kochish 1971: 80-156). Although some secondary issues were not covered in the first Rusin orthographic publication, it was without any doubt a very useful and very influential one.

Kochish applied the proposed orthography rules in the first dictionary of the Voyvodinian Rusin as well. The dictionary entitled Handy Terminology Dictionary SerboCroatian-Rusin-Ukrainian includes the most commonly used words of modern Rusin (Kochish 1972: 5). The entries of the dictionary were based upon the lexical analysis of the material obtained from the weekly newspaper Ruske slovo, the quarterly journal Shvetlosts and textbooks for Rusin language teaching schools. Terms from science, art, culture and mostly from the sociopolitical life of the Rusins were also included in the dictionary in the final phase. The author, who was fully aware that his first-born Rusin dictionary had shortcomings, wrote: "one can expect that in the near future it will be necessary to make corrections of several terms and/or their forms" (Kochish 1972: 7). 


\section{Problems of Rusin Language Orthography}

A serious of articles was published and a few orthographic problems were solved by the members of the Linguistic Section of the Society for the Rusin Language, Literature and Culture, but the Department of Rusin Studies made the first serious step towards a new Rusin orthography. The Department organized a scientific conference called Actual Orthography Problems in the Rusin Language. The conference was supported by the Provincial Secretariat for Science and Technological Development and was held at the Faculty of Philosophy in 2006. The basic directions towards the improvement of the Kochish's rules were specified and even some orthographic problems noticed in the Kochish's orthography rule book published more than four and a half decades ago were solved. It was agreed that in the first phase of this project an orthographic dictionary of the Rusin language was going to be published, and, in the second phase, a text of orthographic rules together with a new, supplemented edition of the orthographic dictionary.

Problems of the Rusin language orthography can be grouped into three sections: $1^{\text {st }}$ section presents establishing a phonological or morphological principle; $2^{\text {nd }}$ section presents dialectization of the Rusin language followed by implementing solutions implemented in other languages; $3^{\text {rd }}$ section presents treatment of foreign words (Feysa, Med’eshi 2007; Feysa 2009).

The first group of problems stems from the interrelation of morphological and phonetic principle concerning writing words, that is from the dominance or influence of etymology or orthoepy on the orthography. In the Introduction of the Orthography Rule-Book of the Rusin language Nikola N. Kochish wrote: "The morphological principle which we have in our writing basically states that we should not write words as they are pronounced, but we should write them bearing in mind their etymology" (Kochish 1971: 3). The example given is the prefixed word rozsipats / pozcunau (not rosipats / pocunau as it is pronounced). The words tkatski / ткацки and tkatstvo / ткацтво (not tkachski / ткачски, tkachstvo / ткачство as it should be if we wanted to include etymology) show that we write many words using the phonetic principle as well. Alexander D. Dulichenko, however, states: "The morphological approach, which remains to be the main one, is complemented by other orthographic principles. One of them is the phonetic principle!" (Dulichenko 2009: 250). The phonetic principle is complementary, not primary, as for example in the Serbian language.

Thus, on the one (morphological) hand, we do not register the consonant assimilation on the basis of voicedness (according to which we 
write for ех. бабка / babka, кнїжка / kn ïzhka, although we pronounce / bapka/, /kn ishka/) and we retain the basic forms of the prefixes (as a matter of fact their final consonant $z$ in roz-, as in rozsipats, predplatsits), and, on the other (phonetic) hand, thousands of words which include historical sound changes caused by $\breve{u}(j-i o t a)$ and front vowels (palatalization), as well as vowel alternations in verb-stems (ablaut), are written without regard to their etymology, in the way they are pronounced. The dilemma of whether to establish a phonological or morphological principle in certain cases causes a great deal of doubt. The dilemma is present in relation to writing suffixes, prefix $z-/ 3$ - (in three variants: s-, z- and zo-) and in case of doubled consonants (for ex. bezzakonni or bezzakoni, scharn èti or shchčarn èti, oddvoyits or odvoyits / беззаконни or беззакони, счарнєти or щарнєти, оддвої оr одвої). Unspecified jurisdiction of the phonetic or morphological principle causes confusion in many other cases: hlasn ik or hlashn ik, pekelni or pekel hi, khudobenki or khudoben ki, nashl idni or nasl idni, storoche or storochye (гласнї or глашнїк, пекелни or пекельни, худобенки or худобеньки, нашлїдни or наслїни, стороче or сторочє) and others.

Another group of problems arises from the artificial framing of the Rusin language. Thus, for example, there were many spelling (and lexical) solutions in Kochish`s orthographic dictionary which have not been accepted by Rusin speakers and, consequently, rejected. Wishing to subordinate the Rusin language to the Ukrainian language, Kochish assigned the role of a dialect to Rusin although the literary Ukrainian language was formed in other sociolinguistic conditions. In practice the doubtful cases were solved by copy-paste procedure. In case it was not known how to solve a problem, the Ukrainian language dictionary was opened and the orthographic solution was copied and pasted in Rusin. A priori reasoning influenced the Rusin orthography directly and brought strange "solutions". Apart from pomilovan 'e i milosts there appeared the unheard poshchada; apart from agent and shpiyun there appeared rozvidn ik; next to pakhul ka there were completely strange pakhol ka and shn izhinka; next to otsena also otsinka; next to prividzen e also primara; only travma (without general form trauma); kloun is prefered (although the Rusins are not familiar with it) to klovn; oberezhno seems more important to Kochish (although the meaning of the word is entirely not recognizable to Rusin speakers) than ostorozhno since it is placed at the beginning of the entry and so on. In this way the Rusin language was aimed to be artificially enriched from the language based on the speech of the Middle Upper Dn ipro Area and the surrounding area (which presents the basis of the Ukrainian Language), instead to be naturally enriched from the Rusin / Rusyn variants of the Carpathian area (which presents 
the basis of the language of the Bachka-Srem Rusins) (помилованє and милоси - пощада; агент and шпиюн - розвиднік; пахулька - пахолька and шнїжинка; оцена - оцинка; привидзенє - примара; травма-траума; клоун - кловн; обережно - осторожно).

The third group of problems concerns the spelling variants of lexemes which generally do not reveal semantic differences. The lexemes present the borrowings from foreign languages. Examples for this group of problems can also be found among the examples of the previous group (such as kloun or klovn, travma or trauma / клоун or кловн, травма or траума), which means that the attempt of false framing of the Rusin language enlarges the emergence of two, three or even more unnecessary variants. Several of the most frequent variants noticed among borrowings are angliyski / anhliyski, granit / hran it, mozaik / mozayik, astronaut / kosmonavt, shpiyun / shpion, anegdota / anekdota, gram / hram, huligan / khuligan, kauzalni / kavzalni, naivni / nayivni, pidzhama / pizhama, Rusiya / Rosiya (английски / английски, гранит / гранїт, мозаик / мозаїк, космонаут / космонавт, шпиюн / шпион, анегдота / анекдота, грам / грам, гулиґан / хулиґан, каузални / кавзални, наивни / наївни, пиджама / пижама, Русия / Росия) and many others. Some of these pairs have been formed by direct contact between the Rusin language and the lending language, and some by indirect contact. In case of the existence of an intermediary language, we often perceive the influence of the intermediary language. Since the members of the group do not carry significant differences in meaning (although they are sometimes notable, for ex. in doktor and dokhtor, kor and khor / докmop and doxmop, кор and xop), it can be said that the variants are redundant. In other words, one form of a lexeme is quite enough.

\section{Improvements of the Orthographic Rules}

Before the conference called The Greatness of Small Linguistic, Literary, Cultural and Historic Traditions held in 2012, which was dedicated to the $30^{\text {th }}$ anniversary of the Department of the Rusin Studies, the text of the Orthographic Dictionary of the Rusin Language was placed on the web-site www.rusnak.info created by Miroslav Silad i. In this way the result of team's work was available to all those who were interested in Rusin orthography to make comments or to give suggestions. The Orthographic Dictionary of the Rusin Language edited by Mikhaylo Feysa (2017) was placed on the web-site of the Faculty of Philosophy.

It has not been our intention to unify several variants of a word into one in the Orthographic Dictionary but to reduce the existing number at least to two of them. For example, there is no need for the following 
four variants: shl iduyutsi, shl iduyushchi, sl iduyushchi, and slj duyutsi (шлїдуюци, шлїдующи, слїдующи, слїующи). After considering the variants carefully we have decided that shl iduyutsi (шлїующи) is quite enough, but there is a justification for using sl iduyushchi (слїующи) in the spiritual sphere. In addition to this, there is no need for Italiyanka, Taliyanka and Italiyka (as Nikola N. Kochish proposed in his Dictionary) since Italiyanka (Италиянка) is derived from Italiya, but Taliyanka (Taлиянка) can be used in everyday speech.

Doublets are simply unavoidable in the Rusin language, or mostly in its lexicon, since Rusin has been under the influence of Slavic and nonSlavic languages - beginning from the Church Slavonic, Hungarian and German in the past to Serbian and English nowadays. We are aware, on the one hand, that it is almost impossible to erase all the traces caused by borrowing, and, on the other hand, that there is no pure language in the world. That is the main reason why we have been tolerant to foreign influences and why we have not tried to unify several variants into one.

We have taken into account several relevant factors such as the time of arrival of a borrowing, the way of its entering a certain field of use, as well as its frequency.

Adaptation of the international diphthongs /au/ and /eu/ should not be unified due to the fact that the words which include the diphthongs did not enter at the same time in Rusin and were not adapted by the same groups of users, so we propose avto, evharistiya, Evropa (авто, евхаристия, Eвроna) etc. but trauma, astronaut, reumatizm, eureka (траума, космонаут, реума, еурека) еtc.

There is no reason to implant the Kochish's form kovboy (ковбой) since, on the one hand, the generally accepted form is kauboy (каубой), and on the other hand, it is closer to the pronunciation of the English word cowboy /kauboi/.

If the form hayziban (гайзибан) has been established in Rusin there is no need to recall German word Eisenbahn pronounced as /ajzenban/.

In the course of resolving orthographic problems several rules have been crystallized that should find a place in a new, or revised version of Kochish's Orthography Rule-Book. Some of them are:

a) if in the use of a noun we feel the presence of a human factor, or a certain personification, and, therefore, the possibility of a particular action, we are inclined to give priority to the genitive forms in ending $-u$, that is, to the ending -zmu (for ex. amaterizmu, bilingvizmu) and to the ending - $v k u$ (for ex. vil ìvku, vipl ùvku);

b) for nouns of new origin (when Serbian is either source or mediating language, mainly for anglicisms) we have mostly added endings $-u /-y u$ (for ex.startu, shlaysu) or both -u/-yu and -e/-ye endings (for ex.avionu/- 
nye, rekordu/-dze) in case that certain nouns have achieved a higher degree of adaptation in the Rusin system;

c) double nominative plural endings are used with masculine nouns in -log, (for ex. sotsiologi/-gove); ending $-i$ is preferred with feminine nouns (for ex. sotsiologi).

One of our aims has been to integrate the gender perspective into the Orthographical Dictionary and that is the reason why the masculine noun entries are frequently followed by the feminine noun entries. For example:

Bun`evets, -vtsa, loc. o Bun`evtsovi, pl. Bun`evtsi, -tsokh;

Bun`evka,-ki, loc. o Bun`evki, pl. Bun`evki, -kokh;

kolega, -gi, pl. kolegi/-gove, -gokh;

kolegin`a, -n `i;

pedagog,-oga, pl. pedagogi,-gokh;

pedagoga, -ogi, pl. pedagogi, -ogokh and pedagogin`a, -n`i, pl. pedagogin i, -n’okh.

Variants with the same (or similar) meanings have been given in alphabetical order within the same entry:

bidni, -noho, bidn `ik, -ka and bidn`ak, -ka;

bilingvist, -ta and bilingvista, -ti;

bombus,-sa, loc. o bombusu, pl. bombusi,-sokh and bonbona ("bombona),-ni, loc. o bonboni, pl. bonboni, -nokh;

vetseyyazikovi,-va,-ve and vetseyyazichni, -na,-ne;

stodvatsetspejtsrochni and 125-rochni,-na,-ne;

benzinov, -va,-vo, benzinovi, -va,-ve and benzinski,-ka,-ke;

zhalbov,-va,-vo and zhalbovi,-va,-ve.

Special attention has been paid to masculine nouns which in the nominative of the singular end in a vowel. They may have two endings in the nominative of the plural, for ex. the nouns ending in final phoneme $/ 0 /$ have both ending - $a /-y a$ (for ex. avta, diska, radiya, stsenariya) and ending -i (evri/-ra, korza/-zou; the form korzou preserves the final vowel $o$ ) in the nominative of the plural.

We have regularly pointed to the nouns which basis are enlarged in certain cases:

bachi,-ika, loc. o bachikovi, pl. bachikove,-okh;

mats, -tseri, loc. o matseri, pl. matseri, -rokh;

kache, -etsa, loc. o kachetsu, pl. kachata,-tokh.

Adjectival paradigm has been provided for the most frequent pronouns and numerals:

moy, -yoho, dat. -yomu, accus. -y/-yoho, instr. moyim, loc. moyim/yomu, pl. moyo, moyikh, dat. moyim, accus. -yo/moyikh, instr. moyima, loc. moyikh; 
von, gen. and accus. yoho (when emphasized) / ho / (od) n'oho / (do) n’ho, dat. yomu (when emphasized) / mu / (gu) n'omu, instr. n im, loc. n`im/n'omu;

tota, tey, dat. tey, accus. totu, instr. totu, lok. tey, pl. toti, tikh;

yeden, yednoho, dat. yednomu, accus. yeden (for non-animate) / yednoho (for animate), instr. z yednim, loc. o yednim/yednomu;

dvoyo coll., dvoyikh, dat. dvoyim, accus. dvoyo, instr. dvoyima, loc. o dvoyikh.

We have paid much greater attention to verbs than Nikola Kochish did. For the non-totive / imperfective verbs we have often provided up to five forms - for the localization of verbal situations into the present segment (pres.), for the localization of verbal situations into the past segment (past), the imperative form for the second person of the singular (and sometimes for the second person of the plural) (imper.), the passive participle form (which sometimes has not been recorded because of the semantics) (pass. part.) and the present participle form (which regularly indicates the form of the third person of the singular of the present tense) (pres. part.). The totive / perfective verbs have four forms, since they are not characterized by the present participle form. Instead of a form for the localization of verbal situations into the present segment, the totive verbs have a form for localization of verbal situations into the future segment (fut.). For example:

zabavyats, pres. -yam, past -yal, imper. -yay, pass. part. -yani, pres. part. -yayutsi;

rakhovats, pres.-khuyem, past -val, imper.-khuj, pass. part.-vani, pres. part. -khuyutsi;

zabetonovats, fut. -nuyem, past -val, imper. -nuy, pass. part. -vani;

potverdzits, fut. -im, past -dzel, imper. -dz, mn. -dztse ( ${ }^{*}$-tstse), pass. part. - dzeni.

The biaspectual verbs have also been taken into account. The biaspectual verbs entries are the most complex ones, because the verbs with two verbal modalities can localize the verbal situations into all three time segments, and besides the forms for the imperative and the passive participle they also have a form for the present participle. For example:

masirats, pres. and fut.-ram, past-ral, imper.-ray, pass. part.-rani, pres. part.-rayutsi;

rimovats, pres. and fut. -muyem, past -al, imper. -muy, pass. part. -ani, pres. part. -muyutsi.

In order to reduce the number of verb forms with the suffix -ira-, we have decided that it would be the best thing to accept the forms identical to the model, and the forms in which this suffix -ira- is replaced by the suffix -ova-. This procedure is in accordance with the procedure 
applied to the verbs with the suffix -isa-, in which the suffix -isa- -is replaced by the suffix-ova-:

adresirats, pres. and fut. -am, past -al, imper. -ay, pass. part. -ani, pres. part. -ayutsi and adresovats, pres. and fut. -suyem, past -al, imper. -suy, pass. part. -ani, pres. part. -suyutsi;

asistirats, pres. -am, past -al, imper. -ay, pass. part. -ani, pres. part. -ayutsi and asistovats, pres.-tuyem, past -al, imper. -tuy, pass. part. -ani, pres. part. - tuyutsi.

Several doublets are made when a foreign suffix or at least final consonant are omitted:

anonim,-ma and anonimus, -sa;

aluminiy,-niya/-niyu and aluminiyum,-yuma/-yumu;

zhandar, -ra, pl. zhandare, -rokh and zhandarm, -ma, pl. zhandarmi, -mokh.

As far as adjectives are concerned they also have doublets. Since possessive adjectives can be used in narrow and in broad sense (for ex. betonov, -va, -vo and betonovi, -va, -ve) some adjective entries are characterized by triplets:

anarkhiyni,-yna,-yne and anarkhichni,-chna,-chne;

biografiyni,-na,-ne and biografski,-ka,-ke;

atletichni,-na,-ne and atletski,-ka,-ke;

genetichni,-chna,-chne and genetski,-ka,-ke;

matserin,-na,-no and matserov,-va,-vo;

betonov,-va,-vo, betonovi,-va,-ve and betonski,-ka,-ke.

The use of ending -ichni is proposed when a noun ends in the ending -іка (metodika > metodichni; matematika > matematichni; logika > logichni); in other cases: -iyni as in analogiyni when a noun ends in the ending -iya < analogiya or -ski as in demokratski when a noun ends in a consonant < demokrat.

In the entries with so-called Ruski Krstur - Kucura variants the differences have been emphasized. In Kochish`s orthographic dictionary the Kucura variants were marked with an asterisk and were treated as ungrammatical. We have checked the situation in the Carpathian area first and if so-called Kucura variants exist in other variants of the Rusin / Rusyn language we have accepted them as grammatical. For example:

bl ishchats, pres.-shchim, past -al, imper.-shch, pl.-shchtse, pass. part. -ani, pres. part. -tsi and bl ishchits, pres.-im, past-shchel, imper.-shch, pl. -shchtse, pass. part. -shcheni, pres. part. -tsi;

bezhats, pres.-zhim, past -al, imper.-zh, pl.-zhtse, pass. part. -ani, pres. part. -tsi and bezhits, pres.-im, past -zhel, imper.-zh, pl.-zhtse, pass. part. -zheni, pres. part. -tsi;

eshchi and ishche, unchanged. 
This also applies to the genitive forms of nouns ending in vowels (for ex. Pera and D ura), which are acceptable both as do Peri/D uri and as do Peru/D uru. As far as the so-called Kucura ending - $l i$ (in the third person plural of the past tense) is concerned, which is confirmed by the Carpathian region, but used only by the older generations, we treat it as obsolete. It can be used, for example, in fiction, in order to characterize a person coming from Kucura.

One of the common problems in Rusin orthography is the duplication or non-duplication of consonants, especially when they are in the end of a prefix or at the beginning of a base. For example:

obbudovats, fut. -duyem, past -al, imper. -duy, pass. part. -ani; oddal 'its, fut. - l`im, past -l’el, imper. -l’, pass. part. -l'eni;

oddanosts, -tsi;

oddzel’en`e,-n`a, loc. o oddzel`en ‘u; Oddzel`en`e za rusinistiku; predd`iya,-d`iyi;

rozzubadlats, fut. -lam, past -lal, imper. -lay, pass. part. -lani;

bezzvuchni, -na,-ne;

zzukosa, unchanged;

zakonni,-onna,-onne and zakonski,-ska,-ske;

bezzakonni,-onna,-onne and bezzakonski,-ska,-ske.

Although the Orthographic Dictionary allows variants we are prone to the principle that, if there are variants-replicas of new loanwords, and there is a consciousness about the model-original, the replicas should be formed according to the models, that is, according to the original forms (for ex. beyzbol, gram, huligan, shpiyun).

This also concerns hiatus. Although the alophone of consonant $y$ (i) is heard between two vowels we do not write it. For example:

alkaloid, -du/-da;

arkhaichni (*arkhayichni), -na, -ne;

ateist ("ateyist) -sta i ateista ("ateyista), -sti;

milion (" miliyon), -na, loc. milionu;

mozaik, -ka;

kokain,-na;

kofein,-nu, loc. kofeinu;

kreirats, pres. and fut. -am, past -al, imper. -ay, pass. part. -ani, pres. part.- ayutsi;

radio,-iya, pl. radiya, -iyokh;

spermatozoid,-da, pl. spermatozoidi,-dokh.

Only several exceptions have been made when we have allowed a vowel in replicas to separate two consonants of the model form. This has been done in order to achieve easier pronunciation. It applies to international suffix -ism $(>i z(e) m)$ too. 
vandaliz[e]m,-zma/-zmu, loc. o vandalizme/-mu;

teiz[e]m,-zma/-zmu, loc. o teizme/-mu;

rit[e]m ("ritam),-tma/-tmu, loc. ritme/-mu;

rit[e]m-sektsiya, -tsiyi;

kab[e]l,-la, loc. o kab[e]lu.

The soft sign ( ) has not been written if there has been no linguistic argument for it. This particularly concerns the ending -an '-in the nominative of the singular in which the soft sign appears by analogy, under the influence of the ending $-n \dot{e}$ in the form of the nominative of the plural:

Verbashchan,-na, pl. Verbashchan`e,-nokh;

D`urd`ovchan,-na, pl. D`urd`ovchan`e,-nokh;

Lichan,-na, pl. Lichan`e,-nokh.

If it may happen that two consonants are viewed as digraphs (two letters that stand instead of one phoneme: $\partial 3, \partial \varkappa, \partial ь, \mathrm{mb}, \mathrm{H}$, ль; respectively dz, dzh, d', t', l', $\left.n^{\prime}\right)$, the apostrophe (') is used to separate the consonants.

nad'zhits, fut. -iyem, past -il, imper. -zhiy, pass. part. -iti;

nad'zvichayno, unchanged;

pred'znak,-ka;

kon'yugatsiya,-iyi;

pred'yedlo,-la;

Tat'yana,-ni;

Yut'yub, gen. Yut'yuba/Yut'yubu, loc. o Yut'yubu;

Zakarpat'ye, -t'ya.

\section{Conclusions}

As far as the orthography rules in the Rusin language are concerned three main groups of problems can be distinguished: establishing a phonological or morphological principle; dialectization of the Rusin language followed by implementing solutions implemented in other languages; treatment of loanwords.

In the new Orthographic Dictionary of the Rusin Language (2017) the author follows the following two guidelines: first, if a particular form is alive, general and integrated in the Rusin system it should be accepted; second, if there are several variants of a loanword, with and without awareness of the original form, the standardization rules should be directed towards the pronunciation of a given word in a given foreign language. There many doublets in the Orthographic Dictionary, since the Rusin language has been under the influence of Slavic and non-Slavic languages - beginning from the Church Slavonic, Hungarian and German in the past to Serbian and English nowadays. 
Special attention has been paid to verbs which was not the case in the first Orthography Rule-Book of the Rusin Language (1971) and, consequently, five verbal forms have been provided for the non-totive / imperfective and biaspectual verbs.

\section{REFERENCES}

Dulichenko, A.D. (2009) Jugoslavo Ruthenica II [Yugoslav Ruthenica II]. Novi Sad: Filozofski fakultet, Oddzel`en`e za rusinistiku, NVU Ruske slovo.

Feysa, M. (2000) Juhoslavyanski Rusini (Rusnatsi) [Yugoslav Rusins]. In: Meaufront M. (ed.) Multilingual European Guide of Cultural Communities and of Maisons de Pays of Europe). Le Cannet: European Federation of the Maisons de Pays. pp. 267-278.

Feysa, M. (2004) Sotsiolingvistichni aspekt ruskoho yazika: Voyvodina [Sociolinguistic Aspect of the Rusin Language: Voyvodina]. In: Magocsi P. R. (ed.) Rusin śkyj jazyk [The Rusin Language]. Opole: Uniwersytet Opolski, Instytut Filologii Polskiej. pp. 373-383.

Feysa, M. \& Medeshi, H. (2007) Pravopisni problemi ruskoho yazika u Voyvodini [Orthographic problems of the Rusin Language in Voyvodina]. In: Plišková, A. (ed.) Jazyková kultúra a jaziková norma v rusínskom jazyku [Language culture and norm in the Rusin language]. Prešov: Prešovská univerzita v Prešove - Ústav regionálnih a národnostných štúdií. pp. 59-65.

Feysa, M. (2009) Tendentsiyi rozvoyu normovan`a ruskoho yazika voyvod anskikh Rusnatsokh [The tendencies of the development of the standard of the Rusin language of the Voyvodina Rusins]. Rusin.1(15).pp.101-109.

Feysa, M. (2010). Nova Srbiya i n èna rusinska man ina [The New Serbia and Its Rusin Minority]. Novi Sad: IK Prometey i KPD DOK.

Feysa, M. (2017) Pravopisni slovn ïk ruskoho yazika [Orthographic Dictionary of the Rusin Language]. Novi Sad: Filozofski fakultet, Oddzel`en`e za rusinistiku. [Online] Available from: http://digitalna.ff.uns.ac.rs/ sadrzaj/2017/978-86-6065-419-1 (Accessed: 5th September 2017).

Gavrilovich, S. (1977) Rusini u Bachkoy i Sremu od sredine XVIII do sredine XIX veka [The Rusins in Bachka and Srem from the middle of the 18th Century to the middle of the 19 th centuries]. Godishn ak Drushtva istorichara Voyvodine. pp. 153-215.

Hornak, M. (2006) Bachko-sremski Rusini [Bachka-Srem Rusins]. In: Feysa, M. (ed.) Rusini [Rusins (1745-2005) I]. Novi Sad: IK Prometey, Filozofski fakultet, Odsek za rusinistiku i KPD DOK. pp. 17-74.

Kochish, M.M. (1971) Pravopis ruskoho yazika [Orthographic RuleBook of the Rusin Language]. Novi Sad: Pokrayinski zavod za vidavan`e uchebn `ikokh. 
Kochish, M.M. (1972) Priruchni terminologiyni slovn ïk serbskohorvatsko-ruskoukrayinski [Handy Terminology Dictionary SerboCroatian-Rusin-Ukrainian]. Novi Sad: Novinsko-vidavatel’na ustanova Ruske slovo.

Kochish, M.M. (1977) Gramatika ruskoho yazika [Grammar of the Rusin Language]. Novi Sad: Pokrayinski zavod za vidavan`e uchebn `ikokh.

Kostelnik, H.1923. Gramatika bachvan'sko-ruskey beshedi [Grammar of BachkaRusin Speech]. RNPD, Ruski Kerestur.

Magocsi, P.R. (ed.) (2004) Rusin skyj jazyk. [The Rusin Language]. Opole: Uniwersytet Opolski - Instytut Filologii Polskej.

Medeshi, L. (1993) The problem of cultural borders in the history of ethnic groups: The Yugoslav Rusins. In: Magocsi, P.R. (ed.) The Persistence of Regional Cultures: Rusyns and Ukrainians in Their Carpathian Homeland and Abroad. New York: Carpatho-Rusin Research Centre. pp. 139-163.

Ramach, Yu. (2002) Gramatika ruskoho yazika [Grammar of the Rusin Language]. Belgrade: Zavod za udzhbenike i nastavna sredstva.

Feysa Mikhaylo - University of Novi Sad (Serbia).

Фейса Михайло - доктор лингвистических наук, профессор кафедры русинского языка и литературы философского факультета университета города Нови Сад (Сербия).

E-mail:fejsam@gmail.com 